\title{
環境計測装置を用いた住生活分析手法の検証と住生活類型化への応用 VERIFICATION OF METHOD FOR ANALYSIS OF LIVING BY USING ENVIRONMENT GAUGES AND APPLICATION OF THIS METHOD FOR LIVING PATTERNS
}

\author{
本間博文*, 若杉智子**, 三輪道子***, 毛利浩美**** \\ Hirobumi HONMA, Chieko WAKASUGI, Michiko MIWA \\ and Hiromi MOURI
}

\begin{abstract}
The purpose of this thesis is to verify the efficiency and proporsition of the scientific method applied to identify the patterns of living, then present the patterns of family living extracted by this method.

During this study, to find out the family living room usage, we invented a completely new study method using the Environmental Gauges.

Based on the occupancy of the room, it was possible to observe the change of the family communication style by daily, weekly or annually, which lead us to find out the new family living patterns.
\end{abstract}

Keywords : environment gauge, study of living, living patterns, finding of room usage, three-generation families, nucleus family

環境計測装置、住生活研究、住生活の類型化、在室判定、三世代同居、核家族

\section{1.はじめに}

近年、家族生活は世帯構成もライフスタイルも急激に多様化し、 当然住空間もそのような多様性を受け入れるべく対応が迫ら扎てい る。そのためには、住生活を空間要求との関連づけのもとに類型化 し、それに対応した空間の.「型」を提示しなければならない。従来 建築計画の分野で取り入れられてきた「住み方調查」の手法ではこ ういった多様な状況に対応することが難しく、多くの研究者によっ て、新たな研究手法開発の試みが行なわれている。住み方調査をべ 一スにしながら、調査事例の中に認められる先駆的な住まい方を見 つけ出し、そのような事例在慎重に考察することにより、将来の変 化の方向を探万うとする試みなどがある。有効な方法とは思われる が、予測が調査者の主観的な判断によるところに問題がある。一

方、アンケート調查を中心とした生活意識調查をもとに、ライフス タイル分析を行うなどの試みも多い注。生活意識調査の場合、多変 量解析の手法と組み合わせて分析するが、この方法ではアンケート の項目選択や組み合わせの根拠および抽出された現象に対する研究 者の判断が結論の妥当性を左右することになり、得られた結論を住 生活の規定要因と判定することが可能かどうかの検証は行われてい ない。生活時間調査注2の手法は以前から使われており、筆者らもこ の方法を用いた調查を行っているが、被調查者が正確に行動を記述
してくれるならば、その資料をもとにかなりの精度で住生活を明 らかにすることが可能である。しかし、この手法は被調査者の負担 が大きく、その結果の信頼性に対する共通理解が得られていない。 居室内にビデオカメラを設置し、家族の行動を観察しようとする試 みもある生3。映像そのものの客観性汕あるが被調査世帯の抵抗もあ り、調查協力戸数も限られ、カメラが設置された状態で平常の生活 が営まれている確証はない。

以上いずれの方法も生活の内部に踏み込んで家族の日常的な生活 を捉らえ、住空間計画に反映できるように生活を類型化することは 難しく、「住み方調査」を超えるものとはなりえず、補助的な方法 に留まっている。

このような状況を踏まえ、本論文は、新たな住生活研究の方法を 提起し、その方法によって家族生活の類型化が可能であることを検 証し、分析した結果の報告である。

\section{2 . 調查方法}

このような新たな手法を提起するにあたり、調査、観察されたデ 一夕は再現性の高いものであることを第 1 の条件とした。そのため の方法として、音、照度、温度のセンサーを住戸内の各居室に設置 し、一定間隔每にメモリーに取り込み、数日にわたり測定を行っ

\footnotetext{
* 放送大学教怶学部 教授・工博

*** 放送大学教荃学部 研究生 (研究当時)

**** 放送大学教善学部 大学院生

**** 放送大学教養学部 研究員 (研究当時)
}

Prof., Faculty of Liberal Arts, The University of the Air, Dr. Eng. Post Graduate Student, Faculty of Liberal Arts, The University of the Air Graduate Student, Faculty of Liberal Arts, The University of the Air Assistant Researcher, Faculty of Liberal Arts, The University of the Air 
表 1 モニター世帯の属性

\begin{tabular}{|c|c|c|c|c|c|}
\hline 宅名 & 対象者 & 家族構成 & 夫の職業 & 子供 & 測定居室 \\
\hline A宅 & 40藏代 & 夫·妻·長女·次女 & 会社貝 & 高校生・高校生 & 居間・DK・主寝室・長女室・次女室 \\
\hline B宅 & 50 歳代 & 夫·妻·長女・長男·母 & 自営業 & 大学生・高校生 & 居間·主寝室·長女室·脣男室・祖母室・客間 \\
\hline C宅 & 50 歳代 & 夫・妻・長女・長男 & 会社買 & 社会人・大学生 & LDK·主寝室·長女室・長男室・客間 \\
\hline D宅 & 40歲代 & 夫・妻・長女・長男 & 会社員 & 大学生・高校生 & LDK·主寝室・長女室・長男室 \\
\hline E宅 & 50歳代 & 夫·妻·晨女・脣男·次女·母 & 会社員 & 社会人・社会人・大学生 & LD・主寝窒・長女室・長男室·次女室・祖母室 \\
\hline
\end{tabular}

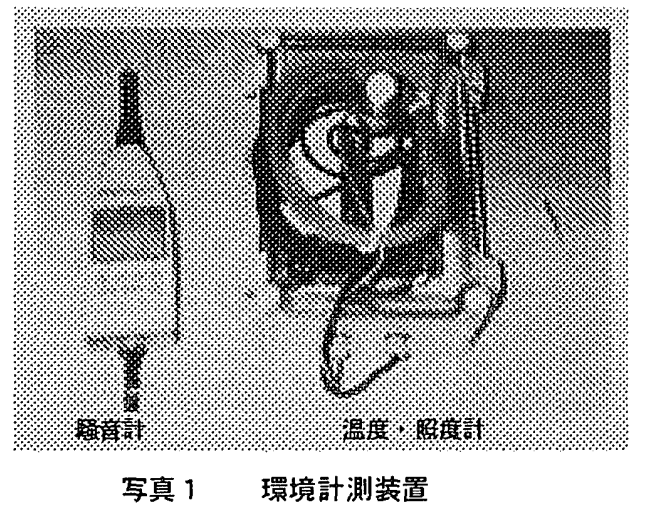

た。集まったデータを分析し、各居室の在室状態を判定する。しか しそのデータから在室状態をどのように判別するか、あるいは在室 状態から、その家族の生活の型をどのように読み取るかが問題であ る。その点については以下の予備調査・モニター調查で明らかにす る。なお、この調查では室内環境を測定することが目的ではない。 従って、各居室に設置した計測器間の校正は特に行なってはいな い。居室ごとの測定データの時系列的な変化をもとに在室判定を 行ったものである。

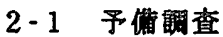

1992年から93年にかけて放送大学関係者22世帯を対象として、環 境計測センサーを用いて実験調査を実施した。照度と温度はコーナ ーシステム社製のリチウム電池を電源とする小型計測器を、騒音レ ベルはAC電源駆動のリオン社製の騒音計を使用した(写真 1$)$ 。各機 器の測定間隔は10分とし、10分間隔ごとの平均温度、平均照度、等 価騒音レベルをメモリーに蓄積。これらの計測セットを被調査世帯 全居室に 3 日間設置した。なお、測定に合わせて生活時間調査表に 家族全員の10分間隔の在室記録と家族構成、年齢、職業、部屋の使 われ方の記入を依頼した。その結果冬期の夜間では十分な精度で在 室状態の判定が出来ることを確認した。つまり、その時期のその時 間帯に居室に在室する場合、なんらかの照明および暖房を必要と

し、その結果がセンサーに反映するからである゙4れ5

\section{2 - 2 モニター闌查}

モニター調査の目的は測定データによる在室判定が、実際の在室 状況をどの程度正確に判定出来るのかを確認する事である。従って モニター調査では、研究の意義と目的を十分に周知したモニター世 帯の抽出が必要であり、放送大学の住居学研究室所属の研究生およ び学生で、40〜50歳代の尃業主婦 5 人（5世帯）を選定した。モ二 ターには測定期間中、センサーの測定間隔にあわせ、家族全員の 10 分間陾の在室状況を正確に記録することを徹底し、1993年12月に各 世帯 3 日間の調查を実施した。センサ一設圆場所をモニター世帯の 各居室の中央・床より高さ $70 \mathrm{~cm}$ に統一した。なお家族全員に不在時 には照明などのスイッチを切ることを依頼した（以後の調査も全て
表 2 説明変数の組み合わせと判定精度

\begin{tabular}{|c|c|c|c|c|}
\hline 説明変数 & $\begin{array}{c}\text { 照度 } \cdot \text { 温度 } \\
\text { Laeq } \text { Lmax }\end{array}$ & 照度 $\cdot$ 温度 & Laeq $\cdot$ Lmax & Laeq $\cdot$ 照度 \\
\hline 正答率 $/ 100$ & 0.849 & 0.864 & 0.776 & 0.833 \\
\hline 相関比 & 0.475 & 0.407 & 0.334 & 0.450 \\
\hline
\end{tabular}

表 3 説明変数別の判別寄与率

\begin{tabular}{|c|c|c|c|c|}
\hline 係数 & 変数 & $\begin{array}{c}\text { 盼度・温度 } \\
\text { Laeq } \text { Lmax }\end{array}$ & 照度·温度 & 照度· Laeq \\
\hline \multirow{4}{*}{ 重为係数 } & 照度 & 0.511 & 0.832 & 0.626 \\
\hline & 温度 & 0.252 & 0.305 & - \\
\hline & Laeq & 0.408 & - & 0.498 \\
\hline & Lmax & 0.065 & - & $=$ \\
\hline \multirow{4}{*}{ 構造係数 } & 照度 & 0.889 & 0.961 & 0.913 \\
\hline & 温度 & 0.607 & 0.657 & - \\
\hline & Laeq & 0.836 & - & 0.859 \\
\hline & Lmax & 0.771 & - & - \\
\hline
\end{tabular}

この指示を行った）。表 1 にモニタ一世帯の家族構成・職業・子供 の年齢・部屋数を示す。

\section{2-2-1 在室判定}

モニターにより正確に記绿された10分間隔の生活時間調査表の在 室状況とセンサーによる測定デー夕を用いて、測定デー夕の妥当性 を判別分析によって検証した。[説明変数］には環境計測装置に記 録されたデー夕の中から夜間 7 時間（17:00〜0:00）２日分の10分間 隄の平均照度（Lux），平均室温 $\left({ }^{\circ} \mathrm{C}\right.$ ），等価騒音レベル（Leq）、区 間内最大瞬時騒音値（Lmax）の 4 項目、計1843セットの測定値を使 用し、〔被説明変数]にはモニターが記録した生活時間調査表から 各居室ごとに同時間帯の[在室]、[不在]を取り出して分析した。

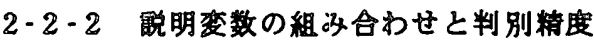

表 2 は説明変数の組み合わせによる判別の精度について、正答率 と相関比を示したものである。正答率は [照度・温度］の 2 変数で 最も高く、 [4 説明変数 $]$ 全ての場合が必ずしも高い正答率を示し ているとは言えなかった。しかし相関比では［4 説明変数］全ての 場合が最大值を示した。[音の 2 変数]は正答率、相関比共に一番 低かつた。表 3 は各説明変.数の寄与に関して、各変数を標準化した 上で説明変数の組合せ別に重み俰数と構造係数を算出したものであ る。以上の結果、在室判定に最も寄与しているのは [照度]であっ た。音 (Leq) の寄与率も比較的高いが騒音計の精度が空内の音源 だけではなく、他の様々な音を拾う事でLeq を変数に取り組むこと が逆に正答率を下げることになった。これが在室判定にマイナスの 要因となるため、以後の調査では瞩音計の使用をやめた。

以上の結果、[照度・温度]の 2 変数だけで90\%近い在室状態の 判別精度が得られた。つ塱り各室の消し忘れなどのスイッチがほぼ 正確に制御されていることが確認できた。

\section{3. 三世代同居家族の住生活}

上記の方法を用いて、1994年1〜翌3月にかけて東京都内及び近郊 


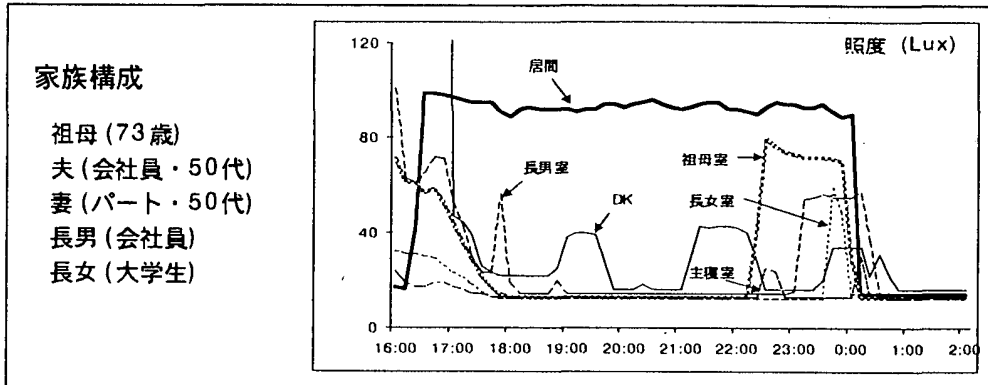

·居間 17:00 0:10まで、95Lux 程度で、ほぼ安定したラインを示し、この間家族の誰 かが在室していることを示している。

祖母室 16:00〜18:00 頃は日没を示すラインを確認し、その後 22:10の入室まで不在 状態を示し、就寝は0:00時頃と思われる。

·長男室 17:50頃瞬時の夕点灯、再び18:50艮男帰宅時に短時間のみ点灯、その後23:10 まで不在状態、就愠は0:10頃と推察。

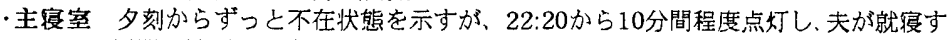
る。0:10居間の消灯と前後して瞬時の夕点灯、この時間に妻が就葠。

•DK 夕刻から30Lux 程度で点灯、19:00から一時間注ど40Luxを示す。この間長男亡 祖母が夕食。21:00過ぎから再び 1 時間程40Luxで点灯し、夫妻亡長女が夕食。0:00 時 頃にも短時間の准用が確認でき、その後16Luxで推移(常夜灯)。光源は 2 多所之推祭。

·長女室 長女は21:00帰宅したが就楦時間まで自室は不在状態を示した。

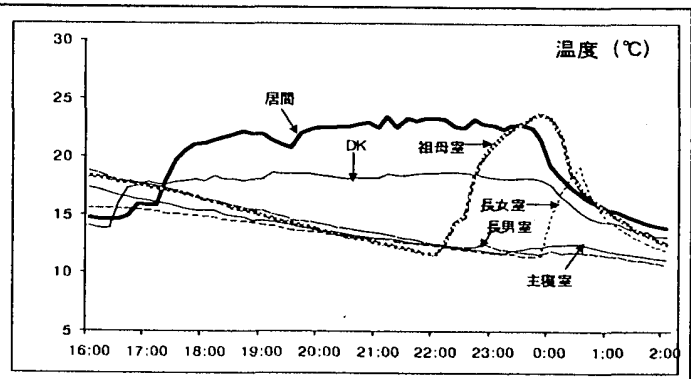

・居間とDK 夕刻〜0:00までずっと高く、22:00に祖母室 の温度が上がる迄、個室は全て不在状態でる。

・祖母室 22:00から使用され、0:00頃就寝を礁認する。

・長女室 居間とDKの值が下がり始める0:00頃暖房が入る が間もなくスイッチが切られて就嘚する。

・主寝室と長男室 暖房を使用することなく就嘚する。

・居間とDKのラインがほぼ連動していることから。この 2 室 は間仕切りを開けて使用していると判断した。

・暖房を使用しない室のラインが外気温と共に下降る。

測定日 : $94 / 3 / 1$ (木)

因 1 TB宅の各居室の照度・温度

パターン $1:$ 一体型

夕刻から夜半まで、1室のラインのみが安定 した形を示し、在宅者全貣が一室に集まって いることを伺わせるタイプ（居間にDKが隣 接し、一体として使用されている場合は連動 するラインが 2 本現饥るが同一空間と会な す)

パターン2：食車一体型

在宅者の個室がそれぞれ動きを示すが、食事 時間には、高い値を示すうインが食事室の一 本のみとなり，他室のラインが低い值を示す 形である。親世带と子世带の生活領域は比較 的明確に確立されているが、食事時間のみは 一室に集まることが推測されるタイプ

\section{パターン $3:$ 分散型}

上下に変動するラインが何本もあり、家族の団 与九の様子分矮光ない世帯。同一食事埸を使 用するが、食事時間も定まらず各自が自室に分 散して生活するタイプ

パターン 4 : 分離型

連動しない高いラインが 2 本以上あり、それ が親世帯の領域と子世帯の領域に別れている 場合で、全体的に㹥褀雑なグラフになるが、 居間或いは食堂など2 2 所の団らんの埸が使 用されていることから二世带住宅的な生活様 式が判断できるタイプ

パターン $5:$ 孭立型

ある個室（単身高夦者室等）のラインが 高值安定しているので、在室状態を示すが、他 の人の出入りが殆ざ䙾えないタイプ

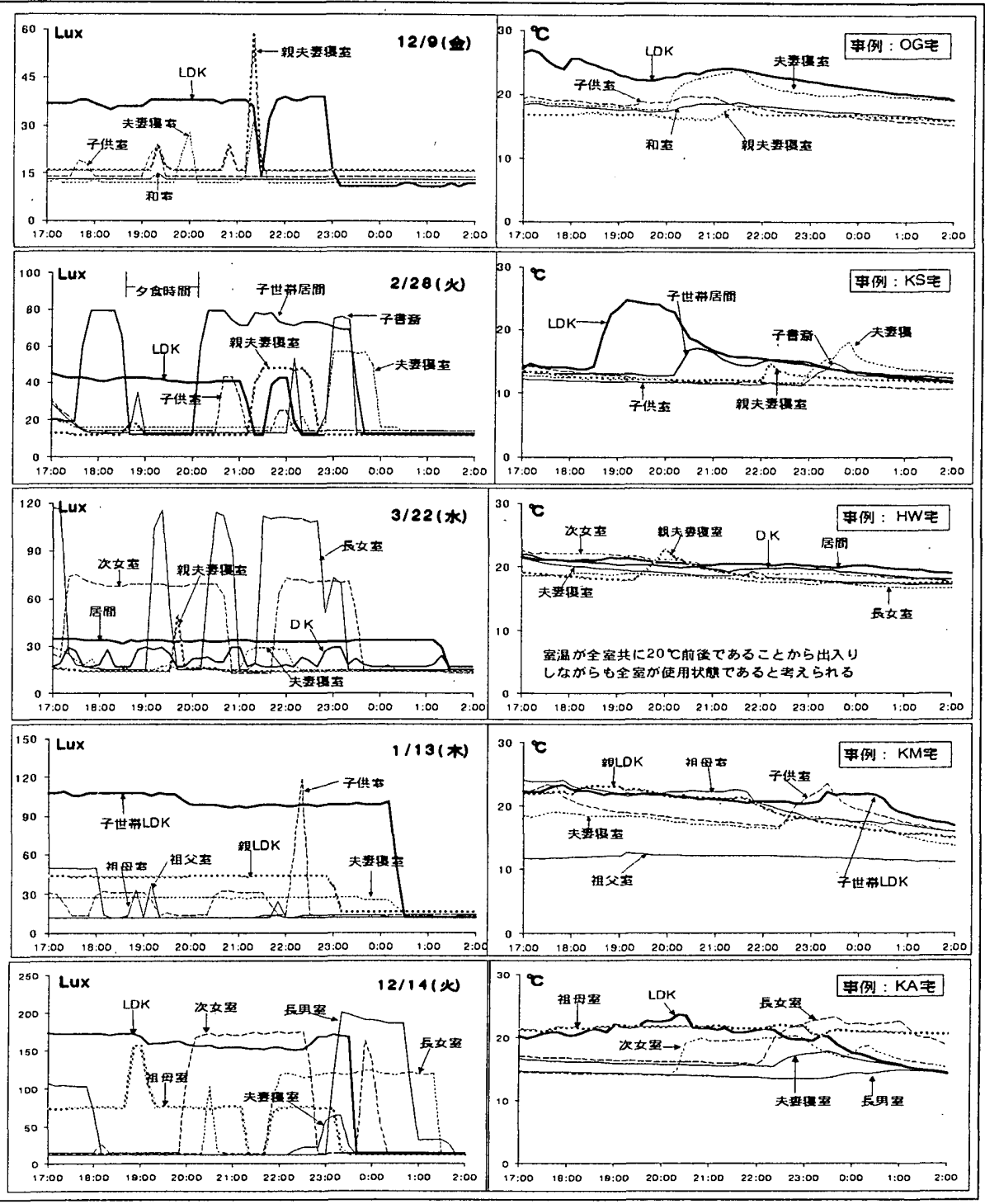

因 2 グラフの形状と生活の型 
在住の三世代同居家族28世帯（放送大学関係者）を対象とし、予備 調査及びモニター調査と同じ照度計と温度計を使用して平日 3 日間 の測定調査を実施した。親世帯と子世帯間のコミュニケーションの あり方等住生活の実態を解明する手掛りを得ようとしたものであ る。この調査からは日常生活に支障をきたさない事を配虑し、各居 室における機器の設置位置注被調査世帯に任せた。また住宅内の主 要な行為時間と各居室の使い方および隣接する部屋の建具の開閉状 態等調査表へ記入することを依頼した。

\section{3-1 グラフによる在室判定と生活の玨}

実施調査では機器の設置位置を限定することができなかったので 各居空ごとの計測值を相互比較することには意味が持てなかった。 よって同一室におけるデータの時系列的変化により在室判定をしな ければいけないことを確認した。そこで我々は各居室の照度と温度 の測定値をグラフ化することを試みた。それにより各室の在室状態 が明らかになり、家族の日常生活を分析することが可能となった。

TB宅の事例をもとに照度と温度のグラフ形状から家族の生活をど のように読み取る事ができるかを示す（前頁図 1参照）。

この結果から親世帯である祖母と子世帯家族の子供が居間とDK （㜆接している）に共に在室する時間が多いことから、TB宅の生活 の型は、親子二世帯が一体となって生活を行っていると判断した。

このようにグラフの形状から、その家族の日常的な交流の様子を 分析することにより家族生活の型分けが可能である。この点を確認 するため、当研究室が先行研究にて三世代同居家族の生活時間調査 をもとに設定した [生活の型] 分類注 ${ }^{6} に$ 対応するグラフ形状の事例 を図 2 に示す。

\section{3-2 3 世代同居家族の迥サイクルの生活}

大半の日本人の日常生活は 1 週間を単位として繰り返されている が、通常の方法では、このような週単位でくり返される生活を浮き 彫りにすることは難しい。この調査方法では、計測器を居室に置く だけなので、被調查者の負担は 1 日でも 1 週間でもそれほど変わら ない。幸い測定に使用したデータロガーは 1 週間程度のデータを記 録することが可能なので、このような利点を生かして週単位で繰り 返さる生活の様子を調べた。1994年12月〜翌 3 月に休日を含む 6 〜 7 日間の測定調査を東京都内及び首都近郊に在住の三世代同居家族 34世帯（放送大学関係者）を対象として実施した。

\section{3-2-1 平日と休日の生活パターンの梪化}

事例：HW宅の分析（図3）では平日は食事時間も一定せず家族 が個室に分散して生活しているが休日は在宅者全員で夕食を共に し、団らんをしていると判断できる。夕食後祖父の部屋は温度が上 昇するが、照明は瞬間のみでその後は点灯していない。おそらく自 室に入って横になるか、テレビを見ているものと判断した。この結 果からこの家族は、平日は家族がそれぞれの個室にこもる傾向の強 い [分散型］と判定した。一方休日は家族が夕食を共にし食後もし ばらく同じ部屋で過ごすことから、[食事一体型]と判定した。

他の調査世帯においても週末を含む 4 5 日のグラフ形状から週

表 4 平日と休日の型

(34世带)

\begin{tabular}{|r|r|r|c|c|c|c|c|}
\hline 平日の型（世带数) & \multicolumn{7}{|c|}{ 休日の型（世带数） } \\
\hline 一体型 & 5 & -体型 & 5 & - & - & - & - \\
\hline 食事一体型 & 12 & 食事一体型 & 8 & 分散型 & 3 & 分離型 & 2 \\
\hline 分散型 & 6 & 分散型 & 2 & 食事一体型 & 4 & - & - \\
\hline 分離型 & 10 & 公離型 & 7 & 一体型 & 1 & 食事一体型 & 2 \\
\hline
\end{tabular}

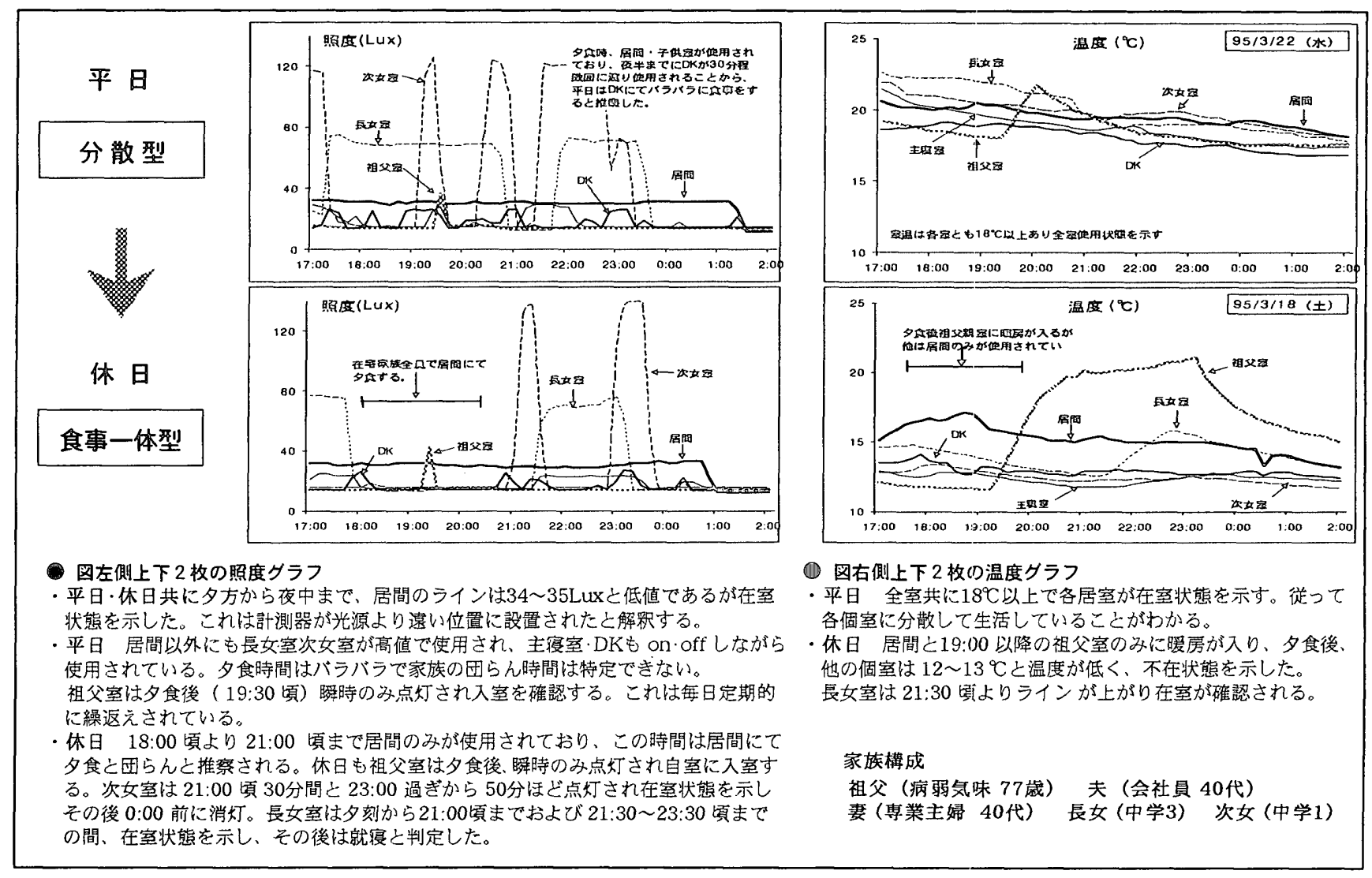

雅例：HW宅の平日と你日の生活パターン 
サイクルで繰返される生活パターンを明らかにすることができた。 [一体型］は平日も休日も一体型を示した。[分離型］には型の変 化はあまり認められないが、中には平日は交流を持たないが休日に は食事を共にする世帯もあった。しかし、[食事一体型] と [分散 型は愊に変る傾向が認められた（表 4）。

\section{3-2-2 生活パターンの年次変化}

1994年の平日 3 日間の調查と95年の一週間の調査で、2 年繼続し て調査した同一世帯10世帯について、平日のデー夕を年次比較した ところ 8 世帯蜎年と同一パターンを示し、2 世帯が前年と異なつ たパターンを示した。その変化の原因を調べたところ、1世帯には 子供が新たに誕生し、上の子の世話を親世帯が見ることから[分離 型］が [一体型］へ変化したこと。もう 1 世帯梳、子供の成長によ り子供室の使用時間が増し、家族に分散傾向が現われ [一体型 $]$ か ら [食事一体型]となったためであった。これは年単位での生活の 変化がグラフに的確に反映されているということを示している。こ の結果は、この報告で提案した研究手法が家族生活の観察に有効で あることを確認するものであった。

\section{4. 核家族の住生活}

我々の提案した手法が家族生活の観察に有効であることが確認で きたので、この照度と温度のグラフによる分析手法を使って核家族 の住生活の様子を調べることにした。とりわけ年長の子供（中高生
以上）を持つ家族の場合、家族共通の空間が個室との関連でどの様 に使われているかを明らかにすることを主要な目的の一つとした。 この測定からは計測器をテイアンドデイ社の小型ロガー（写真 2 ) に換えた。これは単 4 電池 2 個で数ヶ月作動でき 4000 以上のデー夕 を記億できるものである。2 分間隔で照度と温度の瞬時値をメモリ 一に取り込むこととした。瞬時值の方が在室判定にはより適してい るという判断からである。

調査対象とした集合住宅は神奈川県相模原市のUハイツで、築30 年の鉄筋コンクリート造 5 階建、全戸数 710 戸である。今回取り上げ た同一平面型の $3 \mathrm{LDK}\left(88.14 \mathrm{~m}^{2}\right)$ （図 4）は540戸であり、この内 78世帯の協力を得て、1996年12月〜翌3月の間、各世帯一週間の調査 を実施した。

調査方法は機器を各世帯 6 ヶ配布し、平面図(1) (6)の室に被調査 者に設置を依頼し一週間後に回収した。(3)の部屋は洗面浴室なので 分析に当たっては参考にしたが記載グラフには組込まなかった。

それぞれの家族の家族構成や居室の使い方および暖房機について 調査票に記入して鿓ったが、同時に測定期間中の家族全員の帰宅時 間・食事時間・入浴時間・就誛時間等の記録も低頼した。これらの データはグラフ形状から在室状態を判断する際の手がかりとするた めである。これまでの調査では戸建て住宅を対象としていたが、こ の調査では集合住宅を調査対象としたため同一平面型での比較が可 能となった。

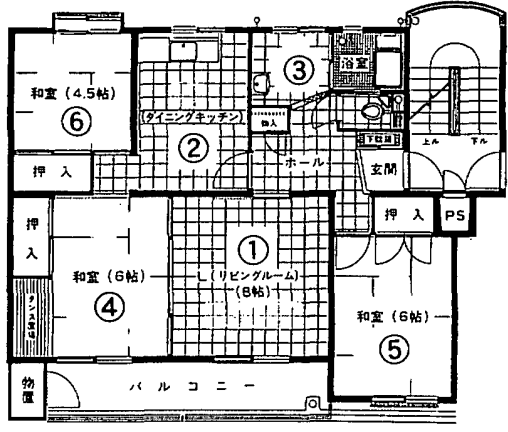

因 43 L D K 平面図

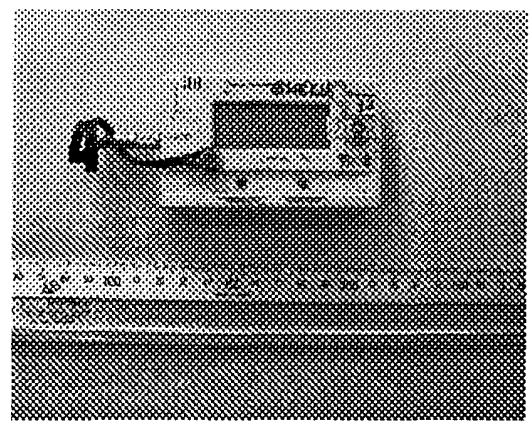

耳真 2 おんどとり（测定器）

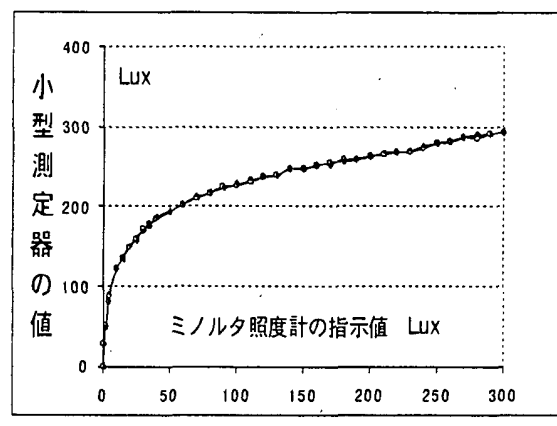

因 5 照度計の㭘定

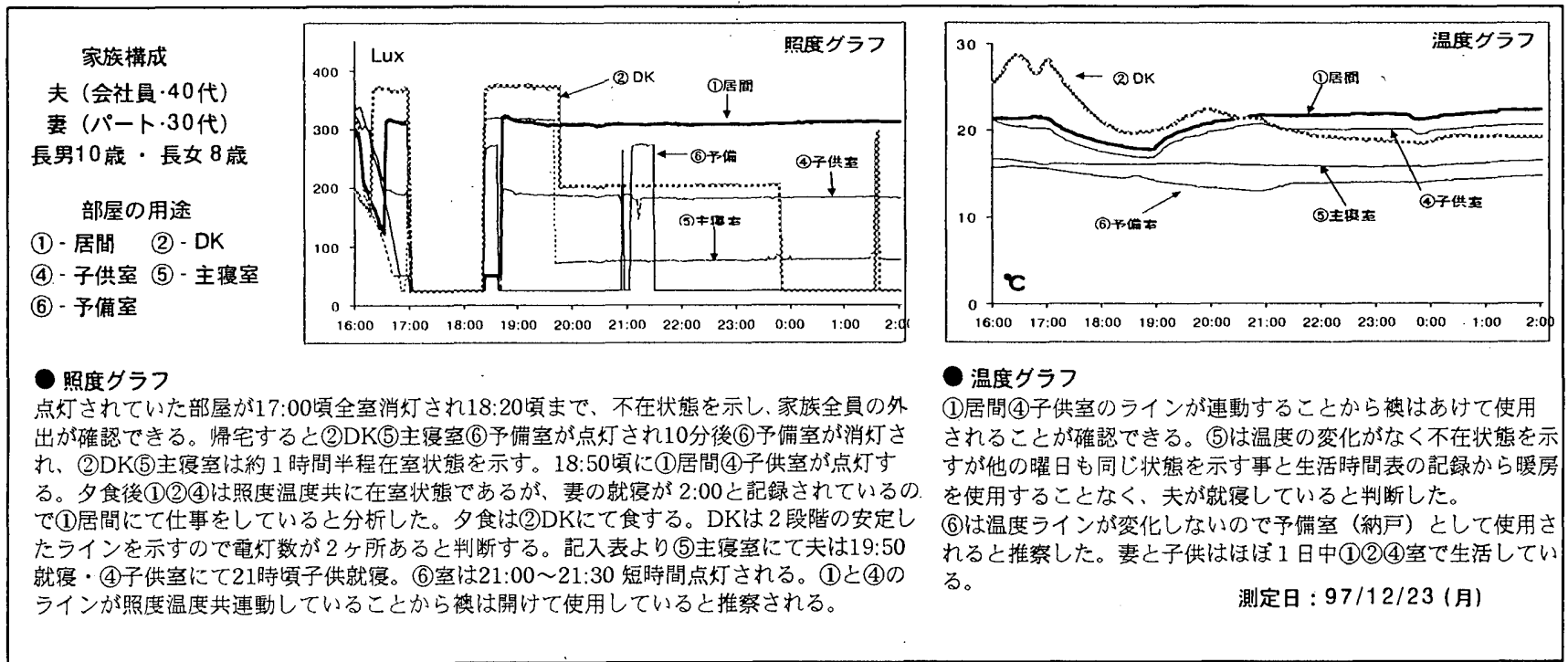




\section{4-1 光センサーの俗蝢珄}

前述したようにこの調查から小型のロガーを用いたが、このロガ 一は2 チャンネルの測定值を取り込むことが可能である。本来は温 度計測用に開発されたものであるが、その片方のチャンネルに簡易 照度センサーを取り付けて測定を行った。ミノル夕の照度計を基準 として、同一の照度の下で明るさを変えて比較計測を行った。ロガ 一の示す出力電圧とミノル夕の照度計の示す基隻照度とを図 5 に示
す。本調査で使った照度計は簡易なものであり、照度の上限は 400 Lux 程度であるが、その筙囲では基準照度計とよく相関しているこ とが読みとれる。当初に述べたように冬の夜間に限っているのでこ の照度センサーは充分に本調査の目的に対応するものであることが 確認できた。

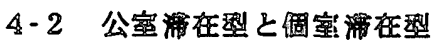

(1) クララフよる判別方法

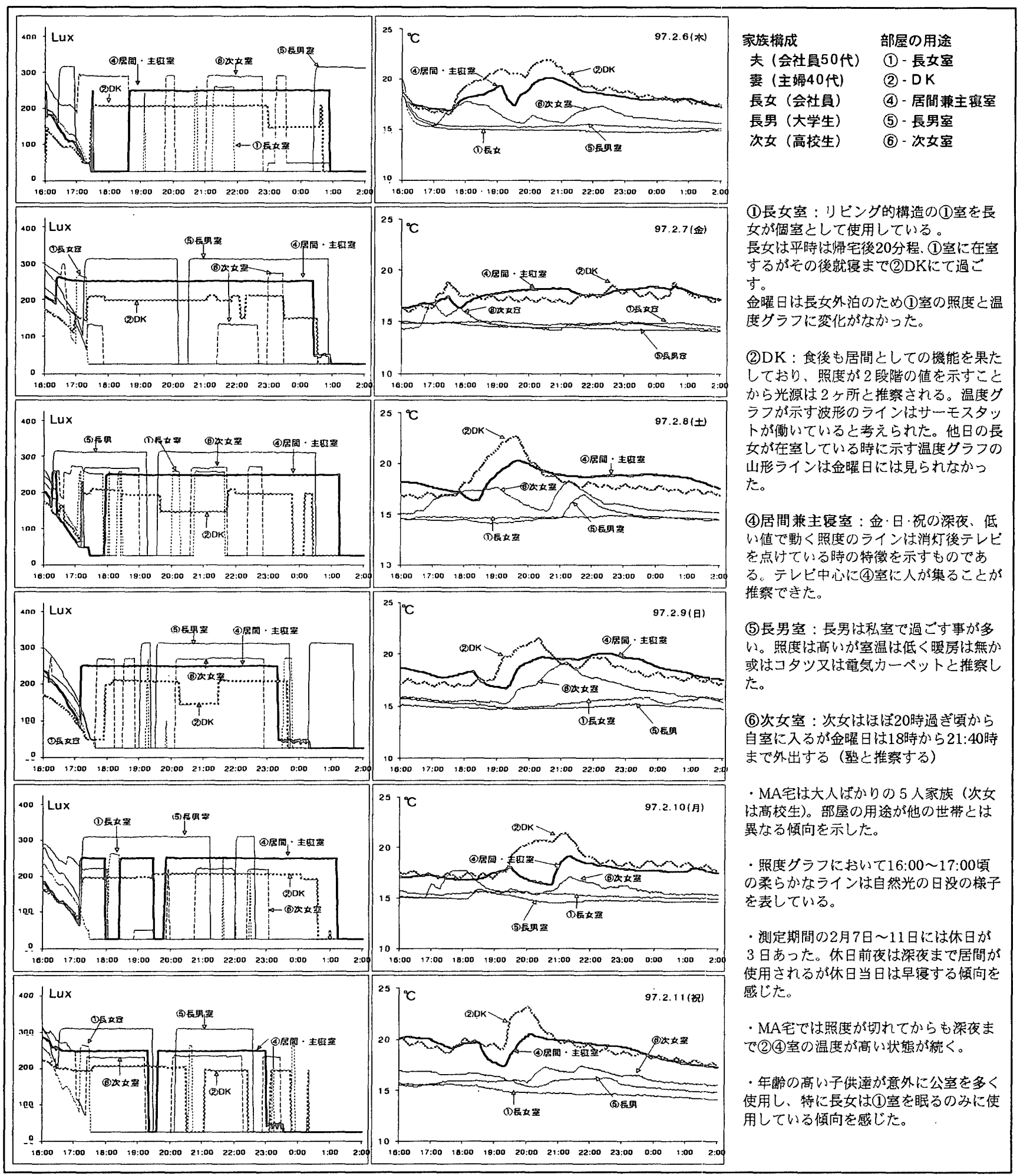

图 $7 \mathrm{MA}$ 宅の一週間の生活バターン 
新しく採用した小型ロガーは瞬時值の記録なので、特に照度グラ フに正確に反応した。図6にSO宅を事例として各居室の在室状態を グラフ形状からどのように読み取るかを記す。生活パターンの判定 にあたっては、照度のグラフを中心に温度のグラフを補助的に参照 して判断した。温度のグラフは室温の変化に時間のずれがあるが、 判定に重要な手がかりを与えてくれる。以上の結果SO宅は生活の大 半を(1)居間を中心に過ごしている公室滞在型家族であることが読み 取れる。

\section{（2）週単位での生活サイクル}

一週間単位の生活がどの様なパターンを示すのかをMA宅の事例 を参考にして図 7 に詳しく説明する。この図から家族全員が個室就 演していること、(4)の居間兼主葠室でテレビ中心に交流時間が多く もたれていることなどが賽える。

このようにして各事例についても詳しく分析を行ない、以下の点 が明らかになった。年齢の高い世带や幼児を抱える若い世帯では曜 日にそれほど影響されることなく 1 週間を通して同じようなグラフ 形状（つまり生活の型）を示す。それ以外の家族、即ち小学高学年 生から20歳代前半の子供を持つ世帯では曜日によりグラフが変化し ているが、平日はほぼ一定した傾向を示し、週末はそれとは異なっ た形状を示すという傾向が窺えた。この結果、1 週間を通しての生 活のパターンを明らかにした上でその成果を住計画に反映させる必 要があるが、この研究はその手がかりとなるものであることが確認 できた。
(3) コミュニケーションとプライバシー

図 8 にYU宅とTA宅の休日のグラフを事例として、1 日の時間軸 に治って個室の在室状況を分析する。YU宅は居間を中心にDK等の 公室で家族が共に過ごす時間が多く、子供達の自室は夕食前後に照 明が点灯するだけで、大半の時間は不在状態を示している。従って 私室は就寝時のみ使用されている。

一方TA宅は家族啲って居間で夕食を拱るものの、長男は食後すぐ 自室に戻り、次男もしばらくすると自分の部屋に入り23時頃就寝す る。温度グラフによると各部屋とも $20^{\circ} \mathrm{C}$ 程度の室温を保ち、在室状 態であることを示している。暖房器具はホットカーペットやヒータ 一を弱く掛けて使用していた。

YU宅怯公室の使用頻度が高い [公室滞在型家族]であり、一方 TA宅は個室に分かれる傾向の強い［個室分散型家族］である。

今回の調査で、比較的年齢の高い子供を持つ家族が15世帯あり、 この中で公室帶在型家族が 7 世帯、個室分散型家族が 8 世帯とほぼ 半々に分かれた。個室分散型と判定した 8 世帯の子供達も自室に籠 もりきりではなく食事時間以外にも居間へ出入りしていることが窥 える。又、兄弟姉妹によっても個々に個室型・公室型と異なること もあった。

以上から高校生や大学生といった年長の子供の場合、自室に籠も る傾向が強いと思われがちであるが、今回の調査では必ずしもそう ではなく長時間公室に滞在する年長の子供も少なくないことが明ら かになった。この点は従来の研究では指摘されていなかったこと

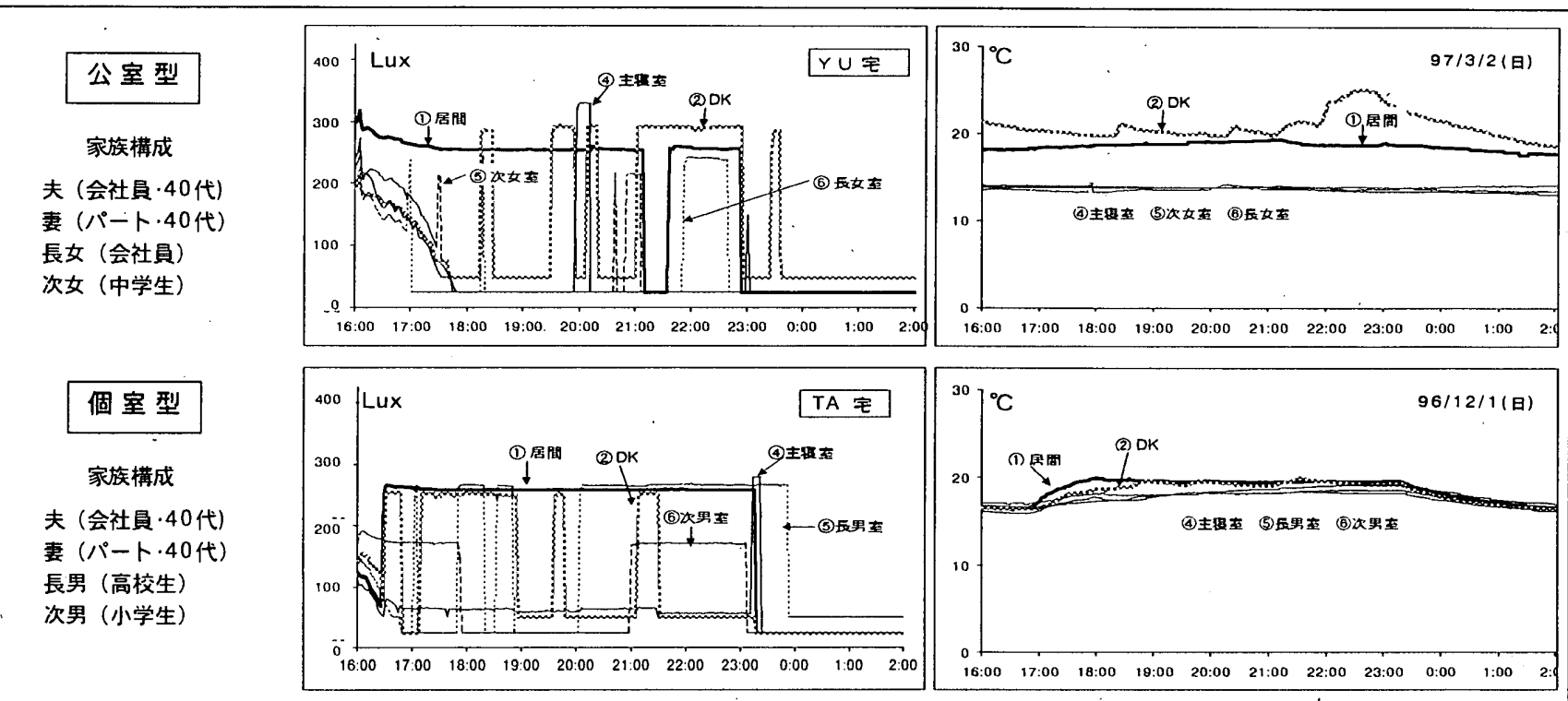

YU宅の部屋の用途：(1) - 居間・ (2) - DK - (4) - 主提室・(5) - 長女室・ (6) - 次女室

照度グラフ：3月2日は(1)居間は夕刻から21:00過ぎまで安定したラインで在室状態を示す。(2)DKが21:00〜23:00頁まで点奵され、この間21:10から40分 間ほど(4)居間が消灯されるので夕食を確認する。子供達の部屋は夕食前は瞬時のみの点灯で不在状態を示し、(1)居間あるいは(2)DKで過ごす。

長女は22:00頃から自室に入る。夕刻のカーブは自然光によるものである。

温度グラフ：(2)DKでの夕食が確認できる。(1)(2)の公室のみ温度ラインが動き、個室は15以下で不在状態を示すが就葠は自室である。

(1)(4)間の襖はラインが連動しないので閉めて使用。毎日夕食時間は21:00過ぎである。YU宅は公室型之言えよう。

TA宅の部屋の用途 : (1) - 居間・ (2) - DK・(4) - 主寝室・(5) - 長男室・ (6) - 次男室

照度グラフ:19:00から(2)DKが消灯され未使用状態となり、子供達の個室の照度も下がり不在状熊となる。この間家族揃って(1)居間で夕食を確認する。 20:00過ぎ長男は自室に㞍り0:00頃まで起きている。次男はそのまま(1)居間に滞在し、21:00頃自室に入り $23: 10$ 頃就寝する。

温度グラフ：は各室が20に满たないが外気温が下がる時刻なので一様に使用されているのが理解できる。(1)(4)間のラインが連動しないので襖は閉めて 使用している。TA宅は個室の使用頻度があり、個室型を示す。 
で、新たな住計画上の課題として今後この点を詳しく調べる必要が ある。

\section{5.まとめ}

本調査の目的は環境測定装置を住戸内の各居室に設置することに よって、当該居室の在室判定が可能であること。そしてその在室状 態の判定から家族生活の類型化が可能である事を検証することで あった。

予備調查によって、この可能性を確認すると同時に、測定時期や 測定方法等を明確にすることが出来た。

モニター調査では各モニターが正確に記録した家族全員の在室状 況と、各居室に設置したセンサーの測定データを判別式に代入して 得た在室判定の結果を比較し、この手法の有効性が確認された。さ らに環境センサーの内、騒音計の精度が逆に災いして在室判定には 不利になることも明らかになった。結果として照度と温度の $2 つ 0$ 指標で $90 \%$ 程度の精度で在室判定が可能であることを確認した。

予備調査・モニター調査のデータ分析から、各居室の在室状況を 判断できること、並びにその値を全居室についてグラフ化すること で家族生活の型を読取ることが可能であることを確認した。

第 1 回の本調査による三世代同居家族の測定デー夕をグラフ化し 夕方から梁夜に及ぶ平日の生活の変化を視覚的に提示した。さらに 典型的なグラフ形状がどのような生活の型に相当するかを示した。

第 2 回の本調査によって 1 週間にわたる生活のパターンが明らか にできることを確認した。平日と休日の違いが明確に示され、従来 の方法では不可能であった長期にわたる家族生活の分析にこの手法 が有効であることを示した。とりわけ、ライフサイクルの進んだ、 つまり成長した子供を抱えている家族は、公室滞在型と、個室分散 型の 2 つ生活パターンがあることが予想され、今後この点を確認 する調査が必要となるだろう。

本手法が適用できる時期は冬期の夜間と限定されたものではある が、従来の手法では明らかにできなかった家族生活の内部に入り込 んだ交流の実態を、当該家族に対するブライバシー侵害という問題 も起こさずに検証することができることを実証した。

以上、本手法は、今後の住生活研究に有効な新しい手法であるこ とが確認された。今後、この手法を用いた家族生活の類型化につい ての報告を継続して行う予定である。

注

注1）住宅都市坛験研究所調查研究第一課編.ライフスタイルに関する研究。 住宅都市整備公团調查研究季報。NO.90, 1989

注2）広原盛明他：住生活におけるコミュニケーションとプライバシ一，日 本建築学会論文報告集, 第148号, pp.61 70, 1968.6

注3）竹下輝和，益田信也他：像場面の分析によるだんらん様式に関する考 察之の1 研究目的亡方法〜その6.日本建築学会学術講演梗概集, 5123,1988

注4）本間博文他：住生活の型分類に関する研究一その1研究方法論の設定， 日本建築学会大会学術講演梗概集, 5128. 1993

注5）本間博文他：住生活の型分類に関する研究ーその 5 睘境センサーによ る在茎判定 日本建築学会大会学術講演梗概集, 5130,1994

注6）本間博文他：三世代同居家族の住部画に関する基磱的研究 - 第 3 報 家族生活の型分類、日本建筑学会大会学術講演梗概集，5126，1989

参考文献

1）山崎さゆり，高橋公子：生活時間からぬた行動之滞留空間の対応関係に 関する研究その 1 - 時間量による生活の類型化, 日本建築学会計画系論
文集, pp.67 74，1997.1

2）山崎さ伭り, 高橋公子：生活時間からみた行動之滞留空間の対応関係に 関する研究その 2 - 行動類型と生活類型の对応関係, 日本建筑学会計画系 論文集, pp.111 118, 1 C 98.2

3）本間博文，世山幹生，只腰昭久他：生活時間から見た家族生活の実態 1 一生活時間粠造に関する研咒その 2 , 日本建筑学会大会学術講演梗概集, 4003,1971

4）児玉好信, 本間博文, 山幹生他：生活時間から見た家族生活の実態 2 生活時間構造に関する研究气の 2 , 日本建築学会大会学術講演梗概集, 4004,1971

5）笹山幹生，只腰昭久，本間博文他：生活時間から見た家族生活の英態 3 一生活時間構造に関する研织その 2 , 日本建策学会大会学術講演梗概集, 4005,1971

6）竹内義雄, 本間博文, 只腰昭久他：生活時間から見た家族生活の実態 4 住生活の構造に関する研究その $2-2$, 日本建築学会大会学術講演梗概集, 5124,1972

7) 笹山幹生, 本間博文, 只腰昭久他：生活時間加与見た家族生活の実態 5 住生活の構造に関する研究その2-3, 日本建築学会大会学術講演梗概集, 5125,1972

8）中里和彦，本間博文，浅井真弓他：住生活の型分類に関する研究その2 三世代同居家族の生活時間配分, 日本建築学会大会学術講演梗概集, 5129,1993

9）太田さち，國嶋道子，梁瀨度子：生活時間・生活行為から外た団らんの 実態，日本建築学会大会学淋講演梗概集，5043，1986

10）川崎直宏, 古川修, 東樋口潥他：コーポ方式需要者のライフスタイル分 析, 日本建筑学会大会学術溝演梗概集, 8005,1978

11）佐野勝則, 竹下輝和, 牧敦司：高柃者のライフスタイルに関する研究, 日本建築学会大会学術講演梗概集, 5158, 1991

12）山東美和子, 渡辺仁史：21世紀のライフスタイルに関する研究システ ム・ダイナミクスによる生活時間の変化の予測, 日本建築学会大会学術 講演梗概集， 5345，1988

13）加茂みどり，高田光雄：寒験住宅 NEXT 21 におけるライフスタイル 提案住戸の住まい方と評価, 日本建築学会大会学術講演梗概集, 5582 , 1996

２003年 2 月 10 日原稿受理，2003年 6 月 12 日採用決定） 